\title{
Comparison of Phytochemicals and Anti-Nutritional Factors in Some Selected Wild and Edible Bean in Nigeria
}

\author{
Awoyinka 0. A.1, Ileola A. 0.2, Imeoria C. N. ${ }^{3}$, Tijani T. D. ${ }^{3}$, Oladele F. C. ${ }^{1}$, Asaolu M. F. ${ }^{2}$ \\ ${ }^{1}$ Department of Medical Biochemistry, College of Medicne, Ekiti State University, Ado Ekiti, Nigeria \\ ${ }^{2}$ Department of Biochemistry, Ekiti State University, Ado Ekiti, Nigeria \\ ${ }^{3}$ Department of Science Laboratory Technology, Ekiti State University, Ado Ekiti, Nigeria \\ Email: olayinka.awoyinka@eksu.edu.ng
}

Received 22 December 2015; accepted 20 February 2016; published 23 February 2016

Copyright (C) 2016 by authors and Scientific Research Publishing Inc.

This work is licensed under the Creative Commons Attribution International License (CC BY).

http://creativecommons.org/licenses/by/4.0/

(c) ()) Open Access

\section{Abstract}

This work aims at analyzing the bioactive and anti-nutritional compounds of edible and wild beans when unprocessed and malted. Qualitative screening of phytochemicals in the various bean samples was determined in ethanol and petroleum ether solvents. Results of the anti-nutritional compositions of unprocessed wild bean extracted with petroleum ether showed there were no traces of saponin and polyphenol, in Feregede and also in edible bean-IT07K-243-1-10 which also had no traces of saponin and tannin. After malting, saponin was totally absent in Pakala, Mucuna, IT97k-499-35, IT07k-243-1-10, and IT04k-333-2 respectively. Polyphenol was also found to be absent in IT07k-243-1-10. Mucuna has the highest phytic acid level $(7.8867 \pm 0.011)$ while Feregede has the lowest phytic acid level $(2.9810 \pm 0.004)$. Otili has the highest anti-trypsin level $(12.001 \pm 0.0013)$. This study showed varying levels of anti-nutrients on the respective bean samples when unprocessed but decreased marginally after malting. It was keenly noted that values derived, either before and after malting were not significantly different $(P \leq 0.05)$ from each other. In all, this study had further shown that malting process enhanced removal of anti-nutrients which invariably would lead to availability of nutrient for animal and human consumption.

\section{Keywords}

Beans, Saponin, Tannin, Trypsin, Polyphenol

\section{Introduction}

Legumes (family: Fabaceae) have been recognized to be the second most valuable plant source for human and

How to cite this paper: Awoyinka O. A., Ileola A. O., Imeoria C. N., Tijani T. D., Oladele F. C. and Asaolu M. F. (2016) Comparison of Phytochemicals and Anti-Nutritional Factors in Some Selected Wild and Edible Bean in Nigeria. Food and Nutrition Sciences, 7, 102-111. http://dx.doi.org/10.4236/fns.2016.72012 
animal nutrition [1]. Legumes are designated to be the third largest family among flowering plants, consisting of approximately 650 genera and 20,000 species [2]. A significant part of human population relies on legumes as staple food for subsistence, particularly in combination with cereals. Even though several common proteinaceous edible legumes (soyabean, cowpea, and others) are available on the market, in most instances, production rate compared with consumption (as food and feed) has remained unmet, and an ever-increasing demand has been witnessed [3]. They are unique foods because of their rich nutrient content including starch, protein dietary fiber, oligosaccharides, phyto-chemicals and minerals. Their nutritional contents contribute to many health benefits to the human beings [4] [5].

Preparation of legume-based foods has remained, to some extent an art, and their nutritional quality has been of interest to both professionals and laymen. The malting process aids in improvement of the organoleptic quality of edible legumes and enhances nutritional quality. Finley et al. and Mitchel et al. [6] [7] reviewed the use of malting to improve the nutritional value of legumes, with particular reference to the generation of functional foods and functional ingredients. Malting is presented as alternatives that are able to reduce or inactivate anti-nutritional factors in legumes, to preserve and possibly enhance the content of isoflavones in legumes, and improves the potential of legumes as functional foods and as ingredients for use in functional foods.

Some of the common anti-nutrients interfere with the use of wild legumes include antivitamins, allergens, cyanogenic glycosides, flatulence factors, goitrogens, hydrogen cyanide, lectins, lysinoalanine, oligosaccharides, phytate, protease inhibitors, saponins, trypsin inhibitors, and several high-molecular-weight phenolic compounds [8]-[12]. However, the concentration and level of these anti-nutrients may vary between legumes and also among subaccessions of the same legume source depending on the location of collection, stage of development, and availability. The greatest impediment to utilize wild or underutilized legumes as a food and feed is the presence of certain anti-nutritional factors, which may not only be toxic, but also can be lethal in extreme situations. For a food researcher, removal of the anti-nutrients from the wild and underutilized legumes with minimal compromise on the nutritional qualities has been a great challenge [13].

Considering the above, it has become imperative for governments along with food researchers and nutritionists to search for cheap, reliable, and safe plant-based resources to accomplish the demand for protein-rich foods. For alleviating hunger and overcoming malnutrition, particularly in children and pregnant women, there is an increased demand in developing countries to explore underutilized legumes [14]-[16]. Exploring wild underutilized legumes can be of high significance for food security, meeting nutritional requirements, and agricultural development. Many of the known wild and underutilized legumes possess adequate amounts of protein, essential amino acids, polyunsaturated fatty acids (PUFAs), dietary fiber, and essential minerals and vitamins comparable to other common legumes, along with the presence of beneficial bioactive compounds. Hence, the present study is geared towards gathering useful information on our localized natural wild and underutilized legumes, which have remained underutilized and unexplored.

\section{Materials and Methods}

\subsection{Collection of Cultivars}

Dry, wild bean-Sphenostyles stenocarpa (Otili), Cajanus cajan (Feregede), Phaseolus lunatus (Pakala), were sourced from the bush of Ado Ekiti environ while the wild type-Mucuna cochindunum (Mucuna), and edible type bean-Phaseolus vulgaris tagged, IT845-2246-4, IT97K-499-35 and IT04K-333-2 were brought from International Institute of Tropical Agriculture (IITA), Ibadan Nigeria. Authentication was carried out at the herbarium of the Plant Science Department, Ekiti State University Ado Ekiti, Nigeria.

\subsection{Physical Characteristic Test}

On all the ten samples collected, bean characteristics which include colour, seed classification and number of seed per grams were determined by modifying the method of Rooney and Miller [17]. From each sample, one hundred whole seeds were randomly selected and placed in a plastic container. The weight of the hundred seeds was determined with a top loading weighing balance. Three replicates were averaged and recorded. The germinative properties were determined according to the method of Institute of Brewing [18]. This was done by taking a graduated meter rule and manual counting of percentage growth of each of the beans during germination (Table 1). 
Table 1. Table of colour, seed classification by shape, weight by 100 beans, shoot length and percentage growth per seed after $5^{\text {th }}$ day germination.

\begin{tabular}{cccccc}
\hline Sample & Colour & Classification of Seed & Weight of 100 Beans & Shoot Length & Percentage Growth PER 10 Seeds \\
\hline Otili & Grey & Oval shape (Bigger) & $26.10 \pm 0.4$ & $2.80 \pm 0.3$ & 80 \\
Feregede & Grey & Oval Shape (Smaller) & $10.65 \pm 0.1$ & $3.47 \pm 0.1$ & 100 \\
$\begin{array}{c}\text { Pakala } \\
\text { Mucuna }\end{array}$ & Variegated & Kidney & $38.70 \pm 0.1$ & $4.37 \pm 0.1$ & 100 \\
IT99K-573-2-1 & Off white & Oval & $78.11 \pm 0.6$ & $3.50 \pm 0.3$ & 70 \\
IT99K-573-1-1 & Off white & Oval & $19.80 \pm 0.3$ & $6.37 \pm 0.1$ & 100 \\
IT97K-499-35 & Off white & Oval & $17.90 \pm 0.4$ & $5.75 \pm 0.3$ & 100 \\
IT07K-243-1-10 & Off white & Oval & $18.70 \pm 0.1$ & $7.43 \pm 0.1$ & 90 \\
IT04K-333-2 & Off white & Oval & $20.10 \pm 0.1$ & $3.36 \pm 0.1$ & 80 \\
IT845-2246-4 & Brown & Oval & $19.30 \pm 0.3$ & $5.50 \pm 0.1$ & 70 \\
\hline
\end{tabular}

\subsection{Malting}

Slight modification as described by Awoyinka and Adebawo [19] was adopted. The ten samples were steeped to give a grain/water ratio 3:4 for $65 \mathrm{~h}$ in a cycle comprising $6 \mathrm{~h}$ wet and $3 \mathrm{~h}$ dry. After the steeping regime the cultivars were spread in germination boxes in the dark and allowed to grow for five days in an atmosphere of near water saturation at room temperature to encourage sprouting. At the end of the germination period samples were dried in oven at $45^{\circ} \mathrm{C}$ for $24 \mathrm{~h}$.

\subsection{Phytochemical Screening}

Phytochemical screening for major constituents was undertaken using standard qualitative methods as described by Sofowora method [20] using petroleum ether and ethanol as solvent respectively. The test for alkaloids was carried out by subjecting $0.5 \mathrm{~g}$ aqueous extract in $5 \mathrm{ml} 1 \% \mathrm{HCl}$, boiled, filtered and Mayer's reagent added [21] [22]. For cardiac glycosides, Killer Kiliani test [22] was adopted ( $0.5 \mathrm{~g}$ of extract was added to $2 \mathrm{ml}$ acetic anhydrate plus $\mathrm{H}_{2} \mathrm{SO}_{4}$ [20]. The presence of flavonoids was determined using $1 \%$ aluminum chloride solution in methanol concentrated $\mathrm{HCl}$, magnesium turnins, and potassium hydroxide solution [23] [24]. For Sterols $1 \mathrm{ml}$ of extract was treated with drops of chloroform, acetic anhydride and conc. $\mathrm{H}_{2} \mathrm{SO}_{4}$ and observed for the formation of dark pink or red colour. Terpernoids was detected by Salkowki's test, $1 \mathrm{ml}$ of chloroform was added to $2 \mathrm{ml}$ of each extract followed by a few drops of concentrated sulphuric acid. A reddish brown precipitate produce immediately indicate the presence of Terpenoids. Well for presence of Quinones, a small portion of extract with conc. $\mathrm{HCl}$ and observed for the formation of yellow precipitate. However, for Oxalate $3 \mathrm{ml}$ portion of extract were added a few drops of ethanoic acid glacial. A greenish black colouration indicates the presence of Oxalate [20].

\section{Anti-Nutritional Analysis}

\subsection{Determination of Tannins}

This was determined by Folin Denis colometric method as modified by Nwosu [25]. Five grams ( $5 \mathrm{~g})$ of the sample was put inside a volumetric flask and $50 \mathrm{ml}$ of distilled water was dispensed inside the volumetric flask. The mixture was shaken for 30 minutes at room temperature and filtered to obtain the extract. A standard tannic acid solution was prepared, $2 \mathrm{ml}$ of the standard solution and equal volume of distilled water were dispersed into a separate $50 \mathrm{ml}$ volumetric flasks to serve as a standard and reagent blank respectively. Then $2 \mathrm{ml}$ of each of the sample extracts was put in their respective labeled flask. The content of each flask was mixed with $35 \mathrm{ml}$ distilled water and $1 \mathrm{ml}$ of the Folin Denis reagent was added to each. This was followed by $2.5 \mathrm{ml}$ of saturated $\mathrm{Na}_{2} \mathrm{CO}_{3}$ solution. Therefore, each flask was diluted to the $50 \mathrm{ml}$ mark with distilled water and incubated for 90 minutes at room temperature. Their absorbance was measured at $760 \mathrm{~nm}$ in a spectrophotometer with the reagent 
blank at zero.

The tannin content was calculated as shown below:

$$
\% \text { Tannin }=\frac{100}{W} \times \frac{a u}{a s} \times C \times \frac{V t}{V a}
$$

where, $W=$ weight of sample

$a u=$ absorbance of test sample

as = absorbance of standard tanning solution

$C=$ Concentration of standard tannin Solution

$V t=$ Total volume of extract

$V a=$ Volume of extract analysed

\subsection{Determination of Saponins}

This was done by the double solvent extraction gravimetric method [21]. Five grams (5 g) of the sample was mixed with $50 \mathrm{ml}$ of $20 \%$ aqueous ethanol solution and incubated for 12 hours at a temperature of $55^{\circ} \mathrm{C}$ with constant agitation. After that, the mixture was filtered through Whatman filter paper. The residue was re-extracted with $50 \mathrm{ml}$ of the ethanol solution for 30 minutes and the extracts weighed together.

The combined extract was reduced to about $40 \mathrm{ml}$ by evaporation and then transferred to a separating funnel and equal volume $(40 \mathrm{ml})$ of diethyl ether was added to it. After mixing well, there was a partition and the other layer was discarded while the aqueous layer was reserved. This aqueous layer was re-extracted with the ether after which its $\mathrm{pH}$ was reduced to 4.5 with dropwise addition of dilute $\mathrm{NaOH}$ solution. Saponin in the extract was taken up in successive extraction with $60 \mathrm{ml}$ and $30 \mathrm{ml}$ portion of normal butanol. The combine extract (ppt) was washed with $5 \% \mathrm{NaCl}$ solution and evaporated to dryness in a previously pre-weighed evaporating dish. The saponin was then dried in the oven at $60^{\circ} \mathrm{C}$ (to remove any residual solvent) and re-weighed. The saponin was determined and calculated as a percentage of the original samples.

$$
\% \text { saponin }=\frac{W_{2}-W_{1}}{W} \times 100
$$

where $W=$ weight of sample used

$W_{1}=$ weight of empty evaporation dish

$W_{2}=$ weight of dish + saponin extract

\subsection{Determination of Trypsin Inhibitor}

This was done using the spectrophotometric method, described by Babar et al., [26]. Five grams (5 g) of the test sample was dispersed in $50 \mathrm{ml}$ of $0.5 \mathrm{~m} \mathrm{NaCl}$ solution and stirred for 30 minutes at room temperature. It was centrifuged and the supernatant filtered through Whatman filter paper. The filtrate was used for the assay. Standard trypsin was prepared and used to treat the substrate solution (N-benzol-D1-arginine-p-anilide; BAPA). The extent of inhibition was used as a standard for measuring the trypsin. In the tube containing 2 ml of extract, 10 $\mathrm{ml}$ of the substrate (BAPA) was added. Also the $2^{\text {nd }}$ part of the standard trypsin solution was added in another test tube containing only $10 \mathrm{ml}$ of the substrate. The latter served as the blank.

The content of the tubes were allowed to stand for 30 minutes and then absorbance of the solution were measured spectrophotometrically at $410 \mathrm{~nm}$ wavelength. One trypsin activity unit inhibited is given by an increase on 0.01 absorbance unit at $410 \mathrm{~nm}$.

$$
\text { Trypsin unit inhibited } / 100 \mathrm{~g}=\frac{A u}{A s} \times 0.01 \times F
$$

where, $A u=$ Absorbance of standard (uninhibited sample)

$$
F=\text { Experimental factor given as } \frac{V f}{V a} \times \frac{1}{W}
$$

where, 
$V f=$ Total volume of extract

$V a=$ Volume of extract analysed

\subsection{Phytate Determination}

This was carried out according to A.O.A.C. [27]. $2 \mathrm{~g}$ of the sample was weighed into a test tube. About $10 \mathrm{ml}$ of distilled water was added. The sample was extracted using $2 \mathrm{ml}$ of $0.2 \mathrm{M} \mathrm{HCl}$ (aq). About $0.5 \mathrm{ml}$ of the extract was pipetted into a test tube fitted with glass stopper. Then, $1 \mathrm{ml}$ of the solution was added in the tube and covered with stopper. The tube was heated in a boiling water bath for 30 min and the tube was covered very well with the stopper for the first $15 \mathrm{~min}$. Then the test tube containing the solution was cooled in ice water for 15 min and allowed to adjust to room temperature. Then the content of the test tube was mixed very well and centrifuged for $30 \mathrm{~min}$. About $1 \mathrm{ml}$ of the supernatant was transferred into another test tube and about $1.5 \mathrm{ml}$ of the solution was added.

The absorbance at $420 \mathrm{~nm}$ against distilled water was measured.

$$
\% \text { Phytate }=\frac{A u}{A s} \times \frac{C}{W} \times \frac{100}{V A} \times V f
$$

$$
\begin{aligned}
& A u=\text { absorbance of test sample } \\
& A s=\text { Absorbance of standard solution } \\
& C=\text { concentration of standard solution } \\
& W=\text { Weight of sample used } \\
& V f=\text { Total volume of extract } \\
& V a=\text { Volume of extract }
\end{aligned}
$$

\subsection{Estimation of Polyphenols}

Polyphenol substances were estimated by Folin-Denis method as modified by Nwosu [25]. About 200 mg defatted material was taken in a $250 \mathrm{ml}$ round bottomed flask and $100 \mathrm{ml}$ of $1 \% \mathrm{HCl}$ in methanol was added. The contents were refluxed for $2 \mathrm{~h}$, cooled, filtered and the volume was made up to $100 \mathrm{ml}$ with acid-methanol after few washings $0.2 \mathrm{ml}$ of extract was taken and $7.5 \mathrm{ml}$ of water and $0.5 \mathrm{ml}$ Folin-Denis reagent were added and mixed. To this, $1 \mathrm{ml}$ of saturated sodium carbonate solution was added and volume made up to $10 \mathrm{ml}$ with water, mixed and the absorbance was measured at $760 \mathrm{~nm}$ after $30 \mathrm{~min}$. The results were calculated as $\mathrm{mg}$ tannic acid equivalents/g sample and expressed as $\mathrm{mg} / 100 \mathrm{~g}$ dry weight.

\section{Results and Discussion}

The seeds of beans (Otili, Feregede, Pakala, and Mucuna) analyzed in this present study are rich in phytochemicals (Table 2-5). As shown in the results, presence or absence of certain bioactive compounds depends on the solvent of extraction used (petroleum ether or ethanol) because of their polar and non-polar nature or the bean form (dry or malted). For instance Oxalate was found absent only in Pakala, and some common beans such as (IT97K-499-35, IT04K-333-2 and IT845-2246-4) when phytochemical screening of ethanol extracts of malted samples was carried out but absent in all bean sample when phytochemical screening of petroleum ether extracts of malted dry samples was performed. The results of the phytochemical screening of petroleum ether and ethanol extracts of malted and dry samples contained phytochemicals such as alkaloids, flavonoids, saponin, terpenoids, quinones, sterols, tannins, phenols (Table 2-5). All these phytochemicals present in these legumes compared favorably with those reported from some medicinal plants found in Nigeria [20]. Alkaloids, comprising a large group of nitrogenous compounds are widely used as cancer chemotherapeutic agents [28]. In the report of John et al. [29] alkaloids also interfere with cell division hence the presence of alkaloids in the plant makes it a possible remedy in the treatment of cancer. They further reported that pure flavonoid compounds such as anthocyanins, quercetin glycosides and tannins, present in the seed displayed antioxidant and anticarcinogenic activity. Presence of tannins suggests the ability to play a major role as antidiarrhoec and antihaemorrhagic agent [30]. The presence of Saponins, another common class of anti-nutrient compounds has been reported to show hypocholesterolemic as well as anti-carcinogenic effects [31]. It is also of immense significance as antihypercholesterol, hypotensive and cardiac depressant properties [22] [32]. 
Table 2. Phytochemical screening of ethanol extracts of dry samples.

\begin{tabular}{|c|c|c|c|c|c|c|c|c|c|c|}
\hline Samples & Alkaloid & Cardiac glycosides & Flavonoid & Phenol & Saponin & Sterol & Tanin & Terpenoid & Quinones & Oxalate \\
\hline Otili & $\mathbf{P}$ & $\mathbf{P}$ & $\mathbf{P}$ & $\mathbf{P}$ & $\mathbf{P}$ & $\mathbf{P}$ & $\mathbf{p}$ & $\mathbf{P}$ & $\mathbf{P}$ & A \\
\hline Feregede & $\mathbf{P}$ & $\mathbf{P}$ & A & A & A & A & $\mathbf{P}$ & $\mathbf{P}$ & $\mathbf{P}$ & A \\
\hline Pakala & $\mathbf{P}$ & $\mathbf{P}$ & $\mathbf{P}$ & $\mathbf{P}$ & $\mathbf{P}$ & $\mathbf{P}$ & $\mathbf{P}$ & $\mathbf{P}$ & $\mathbf{P}$ & A \\
\hline Mucuna & $\mathbf{P}$ & $\mathbf{P}$ & $\mathbf{P}$ & $\mathbf{P}$ & $\mathbf{P}$ & A & $\mathbf{P}$ & $\mathbf{P}$ & $\mathbf{P}$ & A \\
\hline IT99K-573-2-1 & $\mathbf{P}$ & $\mathbf{P}$ & $\mathbf{P}$ & $\mathbf{P}$ & $\mathbf{P}$ & $\mathbf{P}$ & $\mathbf{P}$ & $\mathbf{P}$ & $\mathbf{P}$ & A \\
\hline IT99K-573-1-1 & $\mathbf{P}$ & $\mathbf{P}$ & $\mathbf{P}$ & $\mathbf{P}$ & $\mathbf{P}$ & $\mathbf{P}$ & $\mathbf{P}$ & $\mathbf{P}$ & $\mathbf{P}$ & A \\
\hline IT97K-499-35 & $\mathbf{P}$ & $\mathbf{P}$ & $\mathbf{P}$ & $\mathbf{P}$ & $\mathbf{P}$ & $\mathbf{P}$ & $\mathbf{P}$ & $\mathbf{P}$ & $\mathbf{P}$ & A \\
\hline IT07K-243-1-10 & $\mathbf{P}$ & $\mathbf{P}$ & A & A & $\mathbf{P}$ & A & A & $\mathbf{P}$ & $\mathbf{P}$ & A \\
\hline IT04K-333-2 & $\mathbf{P}$ & $\mathbf{P}$ & $\mathbf{P}$ & $\mathbf{P}$ & $\mathbf{P}$ & $\mathbf{P}$ & $\mathbf{P}$ & $\mathbf{P}$ & $\mathbf{P}$ & A \\
\hline IT845-2246-4 & $\mathbf{P}$ & $\mathbf{P}$ & A & $\mathbf{P}$ & $\mathbf{P}$ & $\mathbf{P}$ & $\mathbf{P}$ & $\mathbf{P}$ & $\mathbf{P}$ & A \\
\hline
\end{tabular}

Note: $\mathrm{P}=$ Present; $\mathrm{A}=$ Absent.

Table 3. Phytochemical screening of ethanol extractsof malted dry samples.

\begin{tabular}{|c|c|c|c|c|c|c|c|c|c|c|}
\hline Malted Samples & Alkaloid & Cardiac glycosides & Flavonoid & Phenol & Saponin & Sterol & Tanin & Terpenoid & Quinones & Oxalate \\
\hline Otili & $\mathbf{P}$ & $\mathbf{P}$ & $\mathbf{P}$ & $\mathbf{P}$ & $\mathbf{P}$ & $\mathbf{P}$ & $\mathbf{P}$ & $\mathbf{P}$ & $\mathbf{P}$ & A \\
\hline Feregede & $\mathbf{P}$ & $\mathbf{P}$ & A & $\mathbf{P}$ & $\mathbf{P}$ & A & $\mathbf{P}$ & $\mathbf{P}$ & $\mathbf{P}$ & A \\
\hline Pakala & $\mathbf{P}$ & $\mathbf{P}$ & $\mathbf{P}$ & $\mathbf{P}$ & $\mathbf{P}$ & A & $\mathbf{P}$ & $\mathbf{P}$ & $\mathbf{P}$ & A \\
\hline Mucuna & $\mathbf{P}$ & $\mathbf{P}$ & $\mathbf{P}$ & $\mathbf{P}$ & $\mathbf{P}$ & A & $\mathbf{P}$ & $\mathbf{P}$ & $\mathbf{P}$ & A \\
\hline IT99K-573-2-1 & $\mathbf{P}$ & $\mathbf{P}$ & $\mathbf{P}$ & $\mathbf{P}$ & $\mathbf{P}$ & $\mathbf{P}$ & $\mathbf{P}$ & $\mathbf{P}$ & $\mathbf{P}$ & A \\
\hline IT99K-573-1-1 & $\mathbf{P}$ & $\mathbf{P}$ & $\mathbf{P}$ & $\mathbf{P}$ & $\mathbf{P}$ & $\mathbf{P}$ & $\mathbf{P}$ & $\mathbf{P}$ & $\mathbf{P}$ & A \\
\hline IT97K-499-35 & $\mathbf{P}$ & $\mathbf{P}$ & $\mathbf{P}$ & $\mathbf{P}$ & $\mathbf{P}$ & $\mathbf{P}$ & $\mathbf{P}$ & $\mathbf{P}$ & $\mathbf{P}$ & A \\
\hline IT07K-243-1-10 & $\mathbf{P}$ & $\mathbf{P}$ & $\mathbf{A}$ & $\mathbf{A}$ & $\mathbf{P}$ & $\mathbf{P}$ & A & $\mathbf{P}$ & $\mathbf{P}$ & A \\
\hline IT04K-333-2 & $\mathbf{P}$ & $\mathbf{P}$ & $\mathbf{P}$ & $\mathbf{P}$ & $\mathbf{P}$ & $\mathbf{P}$ & $\mathbf{P}$ & $\mathbf{P}$ & $\mathbf{P}$ & A \\
\hline IT845-2246-4 & $\mathbf{P}$ & $\mathbf{P}$ & $\mathbf{A}$ & $\mathbf{P}$ & $\mathbf{P}$ & $\mathbf{P}$ & $\mathbf{P}$ & $\mathbf{P}$ & $\mathbf{P}$ & A \\
\hline
\end{tabular}

Note: $\mathrm{P}=$ Present; $\mathrm{A}$ = Absent.

Table 4. Phytochemical screening of petroleum ether extracts of dry samples.

\begin{tabular}{|c|c|c|c|c|c|c|c|c|c|c|}
\hline Samples & Alkaloid & Cardiac glycosides & Flavonoid & Phenol & Saponin & Sterol & Tanin & Terpenoid & Quinones & Oxalate \\
\hline Otili & $\mathbf{P}$ & $\mathbf{P}$ & $\mathbf{P}$ & $\mathbf{P}$ & $\mathbf{P}$ & $\mathbf{P}$ & $\mathbf{p}$ & $\mathbf{p}$ & $\mathbf{P}$ & $\mathbf{P}$ \\
\hline Feregede & $\mathbf{P}$ & $\mathbf{P}$ & $\mathbf{P}$ & A & A & $\mathbf{P}$ & $\mathbf{P}$ & A & $\mathbf{P}$ & $\mathbf{P}$ \\
\hline Pakala & $\mathbf{P}$ & $\mathbf{P}$ & A & $\mathbf{P}$ & $\mathbf{P}$ & $\mathbf{P}$ & $\mathbf{P}$ & A & $\mathbf{P}$ & A \\
\hline Mucuna & $\mathbf{P}$ & $\mathbf{P}$ & $\mathbf{P}$ & $\mathbf{P}$ & $\mathbf{P}$ & $\mathbf{P}$ & $\mathbf{P}$ & $\mathbf{P}$ & $\mathbf{P}$ & $\mathbf{P}$ \\
\hline IT99K-573-2-1 & $\mathbf{P}$ & $\mathbf{P}$ & A & $\mathbf{P}$ & $\mathbf{P}$ & $\mathbf{P}$ & A & $\mathbf{P}$ & A & $\mathbf{P}$ \\
\hline IT99K-573-1-1 & $\mathbf{P}$ & $\mathbf{P}$ & $\mathbf{P}$ & $\mathbf{P}$ & $\mathbf{P}$ & $\mathbf{P}$ & $\mathbf{P}$ & $\mathbf{P}$ & $\mathbf{P}$ & $\mathbf{P}$ \\
\hline IT97K-499-35 & $\mathbf{P}$ & $\mathbf{P}$ & $\mathbf{P}$ & $\mathbf{P}$ & $\mathbf{P}$ & $\mathbf{P}$ & $\mathbf{P}$ & $\mathbf{P}$ & $\mathbf{P}$ & A \\
\hline IT07K-243-1-10 & $\mathbf{P}$ & $\mathbf{P}$ & $\mathbf{P}$ & A & A & $\mathbf{P}$ & $\mathbf{P}$ & A & $\mathbf{P}$ & $\mathbf{P}$ \\
\hline IT04K-333-2 & $\mathbf{P}$ & $\mathbf{P}$ & $\mathbf{P}$ & A & A & $\mathbf{P}$ & $\mathbf{P}$ & $\mathbf{P}$ & $\mathbf{P}$ & A \\
\hline IT845-2246-4 & $\mathbf{P}$ & $\mathbf{P}$ & A & A & $\mathbf{P}$ & A & $\mathbf{P}$ & A & $\mathbf{P}$ & A \\
\hline
\end{tabular}

Note: $\mathrm{P}=$ Present; $\mathrm{A}=$ Absent. 
Table 5. Phytochemical screening of petroleum ether extracts of malted samples.

\begin{tabular}{ccccccccccc}
\hline Samples & Alkaloid & Cardiac glycosides & Flavonoid & Phenol & Saponin & Sterol & Tannin & Terpenoid & Quinones & Oxalate \\
Otili & $\mathbf{P}$ & $\mathbf{P}$ & $\mathbf{P}$ & $\mathbf{P}$ & $\mathbf{P}$ & $\mathbf{P}$ & $\mathbf{P}$ & $\mathbf{A}$ & $\mathbf{P}$ & $\mathbf{A}$ \\
Feregede & $\mathbf{P}$ & $\mathbf{P}$ & $\mathbf{A}$ & $\mathbf{P}$ & $\mathbf{P}$ & $\mathbf{A}$ & $\mathbf{P}$ & $\mathbf{P}$ & $\mathbf{P}$ & $\mathbf{A}$ \\
Pakala & $\mathbf{P}$ & $\mathbf{P}$ & $\mathbf{P}$ & $\mathbf{P}$ & $\mathbf{A}$ & $\mathbf{A}$ & $\mathbf{P}$ & $\mathbf{P}$ & $\mathbf{P}$ & $\mathbf{A}$ \\
Mucuna & $\mathbf{P}$ & $\mathbf{P}$ & $\mathbf{P}$ & $\mathbf{P}$ & $\mathbf{A}$ & $\mathbf{A}$ & $\mathbf{P}$ & $\mathbf{P}$ & $\mathbf{P}$ & $\mathbf{P}$ \\
IT99K-573-2-1 & $\mathbf{P}$ & $\mathbf{P}$ & $\mathbf{A}$ & $\mathbf{P}$ & $\mathbf{P}$ & $\mathbf{P}$ & $\mathbf{P}$ & $\mathbf{P}$ & $\mathbf{P}$ & $\mathbf{A}$ \\
IT99K-573-1-1 & $\mathbf{P}$ & $\mathbf{P}$ & $\mathbf{A}$ & $\mathbf{P}$ & $\mathbf{P}$ & $\mathbf{P}$ & $\mathbf{P}$ & $\mathbf{P}$ & $\mathbf{P}$ & $\mathbf{A}$ \\
IT97K-499-35 & $\mathbf{P}$ & $\mathbf{P}$ & $\mathbf{P}$ & $\mathbf{P}$ & $\mathbf{A}$ & $\mathbf{P}$ & $\mathbf{P}$ & $\mathbf{P}$ & $\mathbf{P}$ & $\mathbf{A}$ \\
IT07K-243-1-10 & $\mathbf{P}$ & $\mathbf{P}$ & $\mathbf{A}$ & $\mathbf{A}$ & $\mathbf{A}$ & $\mathbf{P}$ & $\mathbf{A}$ & $\mathbf{P}$ & $\mathbf{P}$ & $\mathbf{A}$ \\
IT04K-333-2 & $\mathbf{P}$ & $\mathbf{P}$ & $\mathbf{A}$ & $\mathbf{P}$ & $\mathbf{A}$ & $\mathbf{P}$ & $\mathbf{P}$ & $\mathbf{P}$ & $\mathbf{P}$ & $\mathbf{P}$ \\
IT845-2246-4 & $\mathbf{P}$ & $\mathbf{P}$ & $\mathbf{A}$ & $\mathbf{P}$ & $\mathbf{P}$ & $\mathbf{P}$ & $\mathbf{P}$ & $\mathbf{P}$ & $\mathbf{P}$ & $\mathbf{A}$ \\
\hline
\end{tabular}

Note: $\mathrm{P}=$ Present; $\mathrm{A}=$ Absent.

Moreso in the anti-nutritional analysis shown in Table 6 malted ethanolic extract, IT99K-573-2-1 (edible bean) had the highest Saponin with the value $1.22 \pm 0.01$ and found not available in edible bean sample IT07K243-1-10. Phytate content was found to be very high in Mucuna with the value $11.8 \pm 0.02$ while the lowest values are found in both Feregede and Pakala with the values $4.3 \pm 0.1$. Tannin was not found more in Mucuna with the value $1.28 \pm 0.01$ than any other bean sample. Also trypsin inhibitor was found to be significantly higher in Otili with the value of $19.92 \pm 0.02$ compares to other sample. Well polyphenol was not detected in Feregede and Edible bean IT97K-499-35 while Pakala had the highest value of $0.5 \pm 0.02$ while Mucuna had the lowest with value $0.33 \pm 0.01$.

From the result of anti-nutritional factors in malted samples with petroleum ether extract (Table 7), it was observed that saponin level was highest in edible bean IT845-2246-4 with value of $0.87 \pm 0.01$ sample B had the lowest value of $0.039 \pm 0.001$. Phytate level in otili was higher when compared to other bean sample with a value of $6.41 \pm 0.01$ while the lowest was Feregede with the value $2.98 \pm 0.01$. Mucuna had the highest Tannin with the value of $0.5 \pm 0.01$ while the lowest value was found in the edible bean IT97K-499-35 with the value of $0.08 \pm 0.0008$. Trypsin inhibitor was found to be highest in Otili with the value of $12 \pm 0.001$ while the lowest was IT97K-499-35 with the value of $3.002 \pm 0.001$. Polyphenol was found to be highest in Pakala with a value of $0.59 \pm 0.001$ while the lowest was IT97K-499-35 with a value of $0.348 \pm 0.001$. Tannin was not found more in Mucuna with the value $1.28 \pm 0.01$ than any other bean sample. Also trypsin inhibitor was found to be significantly higher in Otili with the value of $19.92 \pm 0.02$ compares to other sample. Well polyphenol was not detected in Feregede and Edible bean IT97K-499-35 while Pakala had the highest value of $0.5 \pm 0.02$ while edible bean IT99K-573-2-1 had the lowest with value $0.33 \pm 0.01$. Important biological activities have been described for fibers, phenolic compounds, lectins, trypsin inhibitors, and phytic acid from beans like enhancement of the bifidogenic effect [33] [34]; antioxidant [35]; anticarcinogenic effects [36]. Nevertheless, it should be noted that some of the commonly considered anti-nutrient compounds like phenols and tannins are now being considered as potential antioxidants with health promoting effects [37]-[40]. Even phytic acid, widely considered to be a major anti-nutrient affecting the bioavailability of minerals and essential trace elements, has now been shown to possess rich antioxidant, anti-carcinogenic, and hypoglycemic activities [41] [42] Hence, depending on the consumer preferences retaining or eliminating these compounds could be facilitated.

\section{Conclusion}

These data provided preliminary evidence that consumption of beans diet such as the localized wild-Otili, Feregede, and Pakala competed favorably with the common edible bean Phaseolus vulgaris in bioactive compounds constituents. This present work provided information on their possible health implication when consumed by human in order to accomplish the demand for protein rich food. 
Table 6. Anti-nutritional factors in dry pulverised samples with absolute ethanol extract.

\begin{tabular}{cccccc}
\hline Bean sample & Saponin & Phytate & Tannin & Trypsin & Polyphenol \\
\hline Otili & $0.583 \pm 0.08$ & $10.5 \pm 0.1$ & $0.43 \pm 0.02$ & $19.92 \pm 0.02$ & $0.3 \pm 0.01$ \\
Feregede & ND & $4.3 \pm 0.1$ & $0.25 \pm 0.03$ & $6.74 \pm 0.3$ & ND \\
Pakala & $0.413 \pm 0.01$ & $4.36 \pm 0.1$ & $0.98 \pm 0.002$ & $7.83 \pm 0.3$ & $0.5 \pm 0.02$ \\
Mucuna & $0.85 \pm 0.001$ & $11.8 \pm 0.002$ & $1.28 \pm 0.01$ & $5.28 \pm 0.1$ & $0.4 \pm 0.02$ \\
IT99K-573-2-1 & $1.22 \pm 0.01$ & $6.84 \pm 0.04$ & $0.83 \pm 0.01$ & $8.39 \pm 0.01$ & $0.33 \pm 0.01$ \\
IT99K-573-1-1 & $0.83 \pm 0.02$ & $7.76 \pm 0.04$ & $0.8 \pm 0.01$ & $6.75 \pm 0.03$ & $0.43 \pm 0.02$ \\
IT97K-499-35 & $0.79 \pm 0.02$ & $7.97 \pm 0.1$ & $0.72 \pm 0.01$ & $6.13 \pm 0.1$ & $0.34 \pm 0.01$ \\
IT07K-243-1-10 & $\mathrm{ND}$ & $7.60 \pm 0.1$ & $\mathrm{ND}$ & $7.14 \pm 0.04$ & $\mathrm{ND}$ \\
IT04K-333-2 & $0.93 \pm 0.02$ & $6.5 \pm 0.2$ & $0.99 \pm 0.05$ & $5.3 \pm 0.16$ & $0.42 \pm 0.01$ \\
IT845-2246-4 & $0.09 \pm 0.06$ & $9.13 \pm 0.17$ & $0.99 \pm 0.06$ & $6.78 \pm 0.02$ & $0.42 \pm 0.01$ \\
\hline
\end{tabular}

NB: Samples in mg/g.

Table 7. Anti-nutritional factors in malted pulverised samples with petroleum ether extract.

\begin{tabular}{cccccc}
\hline Bean sample & Saponin & Phytate & Tannin & Trypsin & Polyphenol \\
\hline Otili & $0.40 \pm 0.001$ & $6.41 \pm 0.01$ & $0.298 \pm 0.01$ & $12.00 \pm 0.001$ & $0.375 \pm 0.001$ \\
Feregede & $0.39 \pm 0.001$ & $2.98 \pm 0.01$ & $0.090 \pm 0.01$ & $5.9 \pm 0.005$ & $0.4 \pm 0.001$ \\
Pakala & $\mathrm{ND}$ & $3.17 \pm 0.01$ & $0.380 \pm 0.12$ & $4.267 \pm 0.001$ & $0.59 \pm 0.001$ \\
Mucuna & $\mathrm{ND}$ & $7.86 \pm 0.01$ & $0.500 \pm 0.10$ & $4.68 \pm 0.001$ & $0.38 \pm 0.009$ \\
IT99K-573-2-1 & $0.84 \pm 0.01$ & $4.84 \pm 0.01$ & $0.210 \pm 0.002$ & $4.10 \pm 0.001$ & $0.42 \pm 0.001$ \\
IT99K-573-1-1 & $0.811 \pm 0.01$ & $5.18 \pm 0.01$ & $0.400 \pm 0.001$ & $3.3 \pm 0.001$ & $0.445 \pm 0.001$ \\
IT97K-499-35 & $\mathrm{ND}$ & $5.66 \pm 0.01$ & $0.080 \pm 0.001$ & $3.002 \pm 0.001$ & $0.348 \pm 0.001$ \\
IT07K-243-1-10 & $\mathrm{ND}$ & $5.8 \pm 0.001$ & $\mathrm{ND}$ & $5.018 \pm 0.001$ & $\mathrm{ND}$ \\
IT04K-333-2 & $\mathrm{ND}$ & $4.81 \pm 0.01$ & $0.401 \pm 0.005$ & $5.4 \pm 0.001$ & $0.5 \pm 0.001$ \\
IT845-2246-4 & $0.870 \pm 0.01$ & $6.00 \pm 0.01$ & $0.410 \pm 0.001$ & $4.86 \pm 0.002$ & $0.47 \pm 0.001$ \\
\hline
\end{tabular}

Note: $\mathrm{ND}=$ Not determined.

\section{Acknowledgements}

The present project was partly funded by 2015 Nigeria Tertiary Education Research Grant (TetFund).

\section{References}

[1] Morris, B. (2003) Legumes. In: Katz, S.H., Ed., Encyclopedia of Food and Culture, Vol. 3, Charles Scribner \& Sons, New York, 1-2.

[2] Doyle, J. (1994) Phylogeny of the Legume Family: An Approach to Understanding the Origins of Nodulation. Annual Review of Ecology, Evolution, and Systematics, 25, 325-349. http://dx.doi.org/10.1146/annurev.es.25.110194.001545

[3] Ali, M. and Kumar, S. (2000) Problems and Prospects of Pulses Research in India. Indian Farm, 50, 4-13.

[4] Vucenik, I. and Shamsuddin, A.M. (2006) Protection against Cancer by Dietary IP6 and Inositol. Nutrition and Cancer, 55, 109-125. http://dx.doi.org/10.1207/s15327914nc5502_1

[5] Hangen, L. and Bennink, M.R. (2002) Consumption of Black Beans and Navy Beans (Phaseolus vulgaris) Reduced Azoxymethane-Induced Colon Cancer in Rats. Nutrition and Cancer, 44, 60-65. http://dx.doi.org/10.1207/S15327914NC441_8

[6] Finley, J.W., Burrell, J.B. and Reeves, P.G. (2007) Pinto Bean Consumption Changes SCFA Profiles in Fecal Fermentations, Bacterial Populations of the Lower Bowel and Lipid Profiles of Human. Journal of Nutrition, 137, 2391-2398. 
[7] Mitchell, D.C., Lawrence, F.R., Hartman, T.J. and Curran, J.M. (2009) Consumption of Dry Beans, Peas, and Lentils Could Improve Diet Quality in the US Population. Journal of the American Dietetic Association, 109, 909-913. http://dx.doi.org/10.1016/j.jada.2009.02.029

[8] Liener, I.E. (1981) Factors Affecting the Nutritional Quality of Soy Product. Journal of the American Oil Chemists' Society, 58, 406-415. http://dx.doi.org/10.1007/BF02582390

[9] Chitra, U., Vimala, V., Singh, U. and Geervani, P. (1995) Variability in Phytic Acid Content and Protein Digestibility of Grain Legumes. Plant Foods for Human Nutrition, 47, 163-172. http://dx.doi.org/10.1007/BF01089266

[10] Burbano, C., Muzquiz, M., Ayet, G., Guadrado, C. and Pedrosa, M.M. (1999) Evaluation of Antinutritional Factors of Selected Varieties of Phaseolus vugaris. Journal of the Science of Food and Agriculture, 79, 1468-1472. http://dx.doi.org/10.1002/(SICI)1097-0010(199908)79:11<1468::AID-JSFA387>3.0.CO;2-G

[11] Beecher, G.R. (2003) Overview of Dietary Flavonoids: Nomenclature, Occurrence and Intake. Journal of Nutrition, 133, 3248S-3254S.

[12] Xu, B. and Chang, S.K. (2009) Total Phenolic, Phenolic Acid Anthocyanin, Flavan-3-ol and Flavonol Profiles and Antioxidant Properties of Pinto and Black Beans (Phaseolus vulgaris L) as Affected by Thermal Processing. Journal of Agricultural and Food Chemistry, 57, 4754-4764. http://dx.doi.org/10.1021/jf900695s

[13] Gupta, J.J., Yadav, B.P.S., Gupta, H.K., Sahoo, S.K. and Agrahar, D. (2001) Nutritive Value of Detoxified Jack Bean (Canavalia ensiformis) Seed for Young Chicks. The Indian Journal of Animal Sciences, 71, 1169-1171.

[14] Coulter, J.B., Sulliman, G.I., Omer, M.I., Macfarlene, S.B., Moody, J.B. and Hendrickse, R.G. (1988) Protein Energy Malnutrition in Northern Sudan: Clinical Studies. European Journal of Clinical Nutrition, 42, 787-796.

[15] Chel-Guerrero, L., Perez-Flores, V., Bentacur-Ancona, D. and Davila-Ortiz, G. (2002) Functional Properties of Flours and Protein Isolates from Phaseolus lunatus and Canavalia ensiformis Seeds. Journal of Agricultural and Food Chemistry, 50, 584-591. http://dx.doi.org/10.1021/jf010778j

[16] Arinathan, V., Mohan, V.R. and De-Britto, A.J. (2003) Chemical Composition of Certain Pulses in South India. International Journal of Food Sciences and Nutrition, 54, 209-217. http://dx.doi.org/10.1080/09637480120092026

[17] Rooney, L.W. and Miller, F.R. (1982) Variation in the Structure and Kernel Characteristics of Sorghum. Proceedings of the International Symposium on Sorghum Grain Quality, International Crop Research Institute for the Semi-Arid Tropics, Hyderabad, 28-31 October 1981, 11-13.

[18] IOB (1981) Report of the Analysis Committee of the Institute of Brewing. Institute of Brewing, London, 14-15.

[19] Awoyinka, O.A. and Adebawo, O.O. (2007) Influence of Variety and Malting Period on Alpha and Beta Amylases in Different Nigerian Maize Cultivars. Technical Quarterly—The Master Brewers Association of Americas, 44, $252-255$ http://www.tqmbaa.org

[20] Sofowora, A. (1993) Medicinal Plants and Traditional Medicines in Africa. John Wiley \& Sons, New York, Chichester, 97-145.

[21] Harborne, J.B. (1973) Photochemical Methods: A Guide to Modern Techniques of Plant Analysis. Chapman A. \& Hall, London, 279.

[22] Trease, G.E. and Evans, W.C. (1978) Pharmacology. 11th Edition, Bailliere Tindall Ltd., London, 60-75.

[23] Kapoor, L.D., Singh, A., Kapoort, S.L. and Strivastava, S.N. (1969) Survey of Indian Medicinal Plants for Saponins, Alkaloids and Flavonoids. Lloydia, 32, 297-302.

[24] Earnsworth, N.R., Berderka, J.P. and Moses, M. (1974) Screening of Medicinal Plants. Journal of Pharmaceutical Sciences, 63, 457-459.

[25] Nwosu, J.N. (2013) Evaluation of the Proximate Composition and Antinutritional Properties of African Yam Bean (Sphenostylis sternocarpa) Using Malting Treatment. International Journal of Basic and Applied Sciences, 2, 157-169.

[26] Babar, V.S., Chavan, J.K. and Kadam, S.S. (1988) Effects of Heat Treatments and Germination on Trypsin Inhibitor Activity and Polyphenols in Jack Bean (Canavalia ensiformis L. DC). Plant Foods for Human Nutrition, 38, 319-324. http://dx.doi.org/10.1007/BF01091729

[27] AOAC (1990) Methods of the Association of Official Analysis Chemists. Official Methods of Analysis. 15th Edition, Assoc. Official Analytical Chemists, Virginia, 1141.

[28] Gurumoorthi, P., Pugalenthi, M. and Janardhanan, K. (2003) Nutritional Potential of Five Accessions of a South Indian Tribal Pulse, Mucuna pruriens var. utilis 1. Investigation on the Total Free Phenolics, Tannins, Trypsin and Chymotrypsin Inhibitors, Phytohaemagglutinins and In-Vitro Protein Digestibility. Tropical and Subtropical Agroecosystems, 1, 153-158.

[29] John, S.K.P., George, S., Primrose, J.N. and Fozard, J.B.J. (2011) Symptoms and Signs in Patients with Colorectal Cancer. Colorectal Disease, 13, 17-25. 
[30] Asquith, T.N. and Butler, L.G. (1986) Interaction of Condensed Tannins with Selected Proteins. Phytochemistry, 25, 1591-1593. http://dx.doi.org/10.1016/S0031-9422(00)81214-5

[31] Koratkar, R. and Rao, A.V. (1997) Effect of Soybean Saponins on Azoxymethane-Induced Prneoplastic Lesions in the Colon of Mice. Nutrition and Cancer, 27, 206-209. http://dx.doi.org/10.1080/01635589709514526

[32] Price, K.R., Johnson, T.I. and Fenwick, G.R. (1987) The Chemistry and Biological Significance of Saponins in Food and Feeding Stuffs. Critical Reviews in Food Science and Nutrition, 26, 22-48.

[33] Ajayi, I.A., Oderinde, R.A., Kajogbola, D.O. and Ukponi, J.U. (2006) Oil Content and Fatty Acid Composition of Some Underutilized Legumes from Nigeria. Food Chemistry, 99, 115-120. http://dx.doi.org/10.1016/j.foodchem.2005.06.045

[34] Tsao, R. (2010) Chemistry and Biochemistry of Dietary Polyphenol. Nutrients, 2, 1231-1246. http://dx.doi.org/10.3390/nu2121231

[35] De Mejia, E., Guzman-Maldonado, S.H., Acosta-Gallegos, J.A., Reynoso-Camacho, R., Ramirez-Rodriguez, E., Pons-Hernandez, J.L., Gonzalez-Chavira, M.M., Castellanos, J.Z. and Nelly, J.D. (2003) Effect of Cultivar and Growing Location on the Trypsin Inhibitors, Tannins and Lectins of Common Beans (Phaseolus vulgaris L.) Grown in Semiarid Highlands of Mexico. Journal of Agricultural and Food Chemistry, 51, 5962-5966. http://dx.doi.org/10.1021/jf030046m

[36] Hughes, J.S., Ganthavorn, C. and Wilson-Sanders, S. (1997) Dry Beans Inhibit Azixymethane-Induced Colon Carcinogenesis in F344 Rats. Journal of Nutrition, 127, 2328-2333.

[37] Hollman, P.C. (2004) Absorption, Bioavailability and Metabolism of Flavonoids. Pharmaceutical Biology, 42 , 74-83. http://dx.doi.org/10.3109/13880200490893492

[38] Bravo, L. (1998) Polyphenol: Chemistry, Dietary Sources, Metabolism and Nutritional Significance. Nutrition Reviews, 56, 317-333. http://dx.doi.org/10.1111/j.1753-4887.1998.tb01670.x

[39] Hagerman, A.E., Riedl, K.M., Jones, G.A., Sovik, K.N., Ritchard, N.T., Hartfield, P.W. and Riechel, T.L. (1998) High Molecular Weight Plant Polyphenolics (Tannins) as Biological Antioxidants. Journal of Agricultural and Food Chemistry, 46, 1887-1892. http://dx.doi.org/10.1021/jf970975b

[40] Cardador-Martinez, A., Loarca-Pina, G. and Oomah, B.D. (2002) Antioxidant Activity in Common Beans (Phaseolus vulgaris L.). Journal of Agricultural and Food Chemistry, 50, 6975-6980. http://dx.doi.org/10.1021/jf020296n

[41] Geil, P.B. and Anderson, J.W. (1994) Nutrition and Health Implications of Dry Beans: A Review. Journal of the American College of Nutrition, 13, 549-558. http://dx.doi.org/10.1080/07315724.1994.10718446

[42] Ferguson, L.R., Chaven, R.R. and Harris, P.J. (2001) Changing Concepts of Dietary Fiber: Implications for Carcinogenesis. Nutrition and Cancer, 39, 155-169. http://dx.doi.org/10.1207/S15327914nc392_1 